\title{
Changes in Land Use Pattern in Uttar Pradesh: A Zone-wise Analysis
}

\author{
Srishti Kushwaha ${ }^{1}$, D.K. Sinha ${ }^{1}$, Ashok Yadav ${ }^{2}$ and Nasim Ahmad ${ }^{1}$ \\ ${ }^{1}$ Department of Agricultural Economics, Dr. Rajendra Prasad Central Agricultural \\ University, Pusa (Samastipur), Bihar PIN-848125, India \\ ${ }^{2}$ Dy. Registrar, Dr. Rajendra Prasad Central Agricultural University, \\ Pusa (Samastipur), Bihar PIN-848125, India \\ *Corresponding author
}

\section{A B S T R A C T}

Keywords

Net sown area, Agro-climatic zone, Current fallow land, food security

Article Info

Accepted:

15 December 2019 Available Online: 20 January 2020
The study was undertaken to study the changes in land use pattern of Uttar Pradesh and its different agro-climatic zones. Land is one of the most essential natural resources for the survival and prosperity of humankind, and it is the platform on which human activities take place. The study is based on the secondary data obtained from the various issues of statistical abstracts of UP government. The study revealed that net sown area declined in the state as a whole and also in almost agro-climatic zones viz. zone-I, zone-III, zone-IV, zone-VI, zone-VIII and zone-IX except three agro-climatic zones viz. zone-II, zone-V and zone-VII in which net area sown showed rising trend. Net area sown had declined in both the state and in agro-climatic zones because of increase in non-agricultural land, current fallow land and fallow land other than current fallow land. Unprecedented population growth resulted in construction of infrastructures like building, roadways, etc. Thus, agricultural-land was converted into non-agricultural land for industrialization and urbanization purposes. Overall, it can be concluded that there is continuous expansion of land towards non-agricultural lands. Declining net sown area is major challenge for policy makers as it will ultimately have adverse effect on food security of the ever growing population of the state. Hence, it is need of the day to increase productivity of the crops as the land is limited and it can't be expanded. There is less scope for horizontal agriculture thus it is time to emphasized on vertical agriculture.

\section{Introduction}

Land is one of the most essential natural resources for survival and prosperity of humankind, and it is the platform on which human activities take place. Land allows for a variety of uses and can satisfy a diverse range of objectives (Young, 1998). Thus, the concept of land use refers to a series of activities done to generate one or more products or services. The same land use can occur on several different parcels of land, and reciprocally, the same land may have several uses. An activity-based definition of land use allows for a detailed quantitative analysis of both economic and environmental impacts, as well as enabling different land uses to be clearly distinguished (FAO, 1998). As a result of increasingly heavy pressure on land resources, agricultural production declines, the quantity and quality of land deteriorates, and there is increasing competition for access 
to land (FAO/UNEP, 1999), and this pressure on land and the overexploitation of land resources have resulted in many forms of degradation such as desertification, loss of biodiversity, deforestation, land degradation, water degradation, etc.

Changing land use is one among the most important environmental challenges for environmental managers across the globe now a day. Land use pattern refers to the distribution and interaction of natural and man-made resources that lie on the earth surface (Kumar, 1986). The interaction between man and nature decides the composition of land uses of a particular region in any dimension. Outcome of natural and socio-economic factors are the land-use and land-cover pattern of a region which is utilized by man in time and space. Thus, the study of land-use/land cover is of prime importance for natural resource management and monitoring of environmental damage, for various developmental and resource planning at global and regional level (Kandrika and Roy, 2008; Roth et. al., 2016).

Uttar Pradesh is India's fifth largest and the most populated state. The Geographical area of the state is 241 thousand sq. $\mathrm{km}$. which is $7.6 \%$ of the country's area, whereas, its share of population is $16.50 \%$. U.P. is, thus, a state with a very large imbalance in its share in respect of country's population and its area. Uttar Pradesh covers a large part of the highly fertile and densely populated upper Gangetic plain. The climate of Uttar Pradesh is predominantly subtropical. The Economy of Uttar Pradesh is basically agrarian in nature. Majority of the population in the state depends on agriculture for livelihood. About 65 percent of the total workforce in the state depends on agriculture and most of them are below poverty line. Agriculture has a paramount role in food production and food security of the state, in particular, and country in general. Irrigation facilities in Uttar Pradesh are relatively well developed. It is one of the indicators for measuring the development of Agriculture in Uttar Pradesh.

Land is a basic need for development of the area. U.P. is, thus, a state with a very large imbalance in its share in country's population and its area. This imbalance has important implications for the development of state's economy. Increased population's pressure on land caused changes in agricultural holding to non-agricultural holding. Rapid land use change has taken place in Uttar Pradesh due to accelerated industrialization and urbanization. Population growth has increased the food requirements. No doubt, urbanization created many developmental opportunities, but, it has also brought serious losses of arable land, forest land and water bodies.

In this paper is an attempt has been made to study the changes in land use pattern in the state of Uttar Pradesh, and its different agroclimatic zones. It has also been attempted to analyze the dynamics and causes of changes in land use after bifurcation of the state.

\section{Materials and Methods}

The study is based on secondary data collected from various published sources like various issues of Statistical diary of Uttar Pradesh, Uttar Pradesh economic survey and also various online resources like websites of Directorate of Economics and Statistics, Ministry of Agriculture and Farmers Welfare, Government of India. The data on land use was collected for the period from 2001-02 to 2014-15.

On the basis on rainfall, terrain and soils the state, has been divided into nine agro-climatic zones. Zone-wise compound growth rates were worked out using exponential model as follows: 


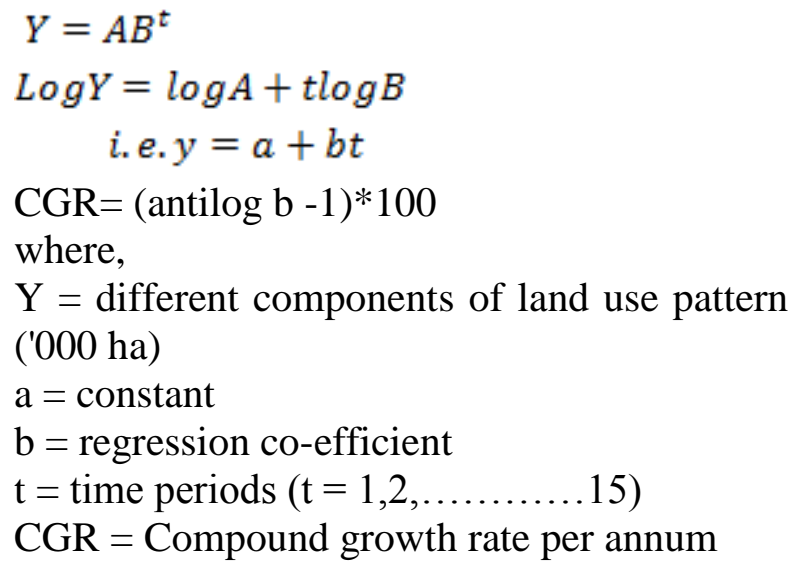

\section{Results and Discussion}

Table 1 showed the changes in land use pattern during the periods between TE-2003 and TE-2015, in the state of Uttar Pradesh. It was observed from the table that forest area decreased from $6.98 \%$ in TE-2003 to $6.86 \%$ in TE-2015. Compound growth rate was found to be negative $-0.07 \%$ per annum. The decline in forest land was due to deforestation of forest land for industrialization and construction of building for residential and other purposes. Area under non-agricultural uses and current fallow land revealed increasing trend i.e., $10.33 \%$ to $12.36 \%$ \& $4.57 \%$ during the period of investigation. The positive growth rates for these categories of land were found to be $0.63 \% \& 0.15 \%$ per annum.

Non-agricultural land showed increasing trend due to shift of population to urban area, industry and construction of bridges, highways and roads, etc. on the other hand, due to low productivity, farmers did not cultivate some areas and hence, current fallow land registered increasing trend in the state. Barren and unculturable land, permanent pasture and other grazing land, land under miscellaneous tree crops and groves not included in net sown area, culturable waste land, and fallow lands other than current fallows were found declining over all periods. Further, it was observed that the net sown area reduced from $69.19 \%$ to $68.55 \%$ during the period TE-2003 to TE-2015 and growth rate was estimated $-0.04 \%$ per annum. The decline in net sown area was due to leaving land idle because productivity of these categories of lands was not cost effective. Decline in net sown area is of great concern, since this will pose a threat to nutritional security in the state, in particular, and nation, in general.

\section{Zone-wise land use pattern of Uttar Pradesh}

\section{Agro-climatic zone-I}

Table 2 revealed the changes in land use pattern in agro-climatic zone-I (Tarai and Bhabhar Zone) of UP which indicated that forest land had enhanced from $10.61 \%$ in TE2003 to $13.80 \%$ in TE-2015. The growth rate was also found positive which emphasized the rising trend in forest land. Enhanced forest land would have been due to Governmental afforestation policy so as to maintain the ecological balance. Area under nonagricultural uses registered accelerated i.e. from $11.17 \%$ in TE-2003 to $12.49 \%$ in TE2015 with a positive growth rate $0.40 \%$ per annum. The reasons for increasing trend in non-agricultural land may probably be attributed to the factors as explained earlier. Barren and unculturable land, permanent pasture and other grazing land, land under miscellaneous tree crops and groves, culturable waste land, fallow lands other than current fallows and current fallow showed decreasing trend i.e. $-1.40 \%,-0.15 \%,-0.94 \%$, $-0.94 \%,-0.74 \%$ and $-0.17 \%$ per annum, respectively. The reason behind decline in these categories of land might be on account of shifting of land towards forest land. In this zone the net sown area had also been found shrinking i.e. from $72.58 \%$ in TE-2003 to $69.18 \%$ in TE-2015 and growth rate could be computed to be $-0.13 \%$ per annum. 


\section{Agro-climatic zone-II}

The changes in land use pattern in agroclimatic zone-II (Bundelkhand zone)(Table-3) revealed that the net area sown increased from $67.02 \%$ in TE-2003 to $68.94 \%$ in TE-2015, the growth rate was estimated to be $0.08 \%$ per annum. Reduction in forest, barren and unculturable land, permanent pasture and other grazing land, culturable waste land, fallow lands other than fallow and current fallow may be one of the reasons for increase in net sown area in this region as the growth trends for these categories of land were obtained negative.

Area under non-agricultural uses and land under miscellaneous tree crops and groves were also found increasing during the period of investigation. The reason for increase in non-agricultural land was same as explained earlier.

\section{Agro-climatic zone-III}

The results of analysis of land use pattern in agro-climatic zone-III (Eastern plain zone) pointed out that net area sown reduced from $67.46 \%$ to $66.46 \%$ during the period TE-2003 to TE-2015, but its growth rate was computed to be positive $(0.02 \%)$. The cultivator might have converted fallow land other than current fallows, culturable waste land for cultivation of crops as their growth figured out as negative. Non-agricultural land set increasing trend from $12.30 \%$ to $15.14 \%$ during the study period showing positive CGR $0.78 \%$ per annum.

\section{Agro-climatic zone-IV}

Table 5 shows the change in land use pattern in agro-climatic zone-IV (North Eastern Plain Zone). It had been observed from the table that net area sown reduced from $73.28 \%$ to $72.57 \%$ during the period TE-2003-TE-2015, the compound growth rate for the same was estimated negative $-0.02 \%$. The reason for decline in net area sown may probably be due to the increase in non-agricultural land and forest land. Non-agricultural land had increased with the growth rate of $0.39 \%$ per annum. The land under forest could rise at the compound annual growth rate of $0.50 \%$ per annum.

\section{Agro-climatic zone-V}

Land use pattern in agro-climatic zone-V (South western dry plain zone) presented in Table 6 revealed that the net area sown increased from $75.91 \%$ to $76.08 \%$ during the period of investigation and in terms of compound growth, it increased at $0.02 \%$ per annum. The reason behind increase in net area sown may probably be due to large decline in the culturable waste land and forest land, permanent pasture and other grazing land, fallow lands other than current fallows and current fallow.

Besides this, increasing trend was observed for non-agricultural land and land under miscellaneous tree crops and groves. The cause for increase in this was probably owing to the fast pace of urbanization on the other hand, the enhanced area under miscellaneous tree crops and groves was subject to the awareness among people to reduce environmental pollution and Government schemes of National Horticultural mission in the state.

\section{Agro-climatic zone-VI}

Table 7 showing the changes in land use pattern in agro-climatic zone-VI (Western plain zone) of Uttar Pradesh indicated that the net sown area in this zone declined from $76.41 \%$ in TE-2003 to $73.60 \%$ in TE-2015 and its compound annual growth rate being $0.23 \%$ per annum. 
Table.1 Land utilization pattern of Uttar Pradesh

\begin{tabular}{|c|c|c|c|}
\hline & & & Area 000'ha) \\
\hline Particulars & TE-2003 & TE-2015 & $\begin{array}{l}\text { CAGR }(\%) \\
\text { from } 2001-15\end{array}$ \\
\hline Geographical area & $\begin{array}{c}24201.59 \\
(100.00)\end{array}$ & $\begin{array}{r}24201.59 \\
(100.00)\end{array}$ & \\
\hline Forest & $\begin{array}{c}1688.73 \\
(6.98)\end{array}$ & $\begin{array}{c}1658.28 \\
(6.85)\end{array}$ & -0.07 \\
\hline Area under non- agricultural uses & $\begin{array}{l}2501.14 \\
(10.33)\end{array}$ & $\begin{array}{l}2988.50 \\
(12.35)\end{array}$ & 0.63 \\
\hline Barren and unculturable land & $\begin{array}{l}595.97 \\
(2.46)\end{array}$ & $\begin{array}{c}468.29 \\
(1.93)\end{array}$ & -0.85 \\
\hline Permanent pasture and other grazing land & $\begin{array}{l}69.80 \\
(0.29)\end{array}$ & $\begin{array}{l}65.40 \\
(0.27)\end{array}$ & -0.17 \\
\hline $\begin{array}{l}\text { Land under misc. tree crops and groves not included in net area } \\
\text { sown }\end{array}$ & $\begin{array}{l}345.55 \\
(1.43)\end{array}$ & $\begin{array}{r}326.77 \\
(1.35)\end{array}$ & -0.20 \\
\hline Culturable waste land & $\begin{array}{l}517.36 \\
(2.14)\end{array}$ & $\begin{array}{c}412.88 \\
(1.71)\end{array}$ & -0.75 \\
\hline Fallow lands other than current fallow & $\begin{array}{l}631.61 \\
(2.61)\end{array}$ & $\begin{array}{c}528.43 \\
(2.19)\end{array}$ & -0.61 \\
\hline Current fallow & $\begin{array}{c}1106.71 \\
(4.57)\end{array}$ & $\begin{array}{c}1152.65 \\
(4.77)\end{array}$ & 0.15 \\
\hline Net area sown & $\begin{array}{c}16744.73 \\
(69.19)\end{array}$ & $\begin{array}{c}16569.25 \\
(68.55)\end{array}$ & -0.04 \\
\hline
\end{tabular}

Figures in brackets indicate percentage value, Source: Statistical abstract of Uttar Pradesh

Table.2 Land utilization pattern of agro-climatic zone-I

\begin{tabular}{|l|c|c|c|}
\hline \multicolumn{5}{|c|}{ (Area 000'ha) } \\
\hline Particulars & TE-2003 & TE-2015 & CAGR(\%) 2001-15 \\
\hline Geographical area & 1786.55 & 1786.55 & \\
\hline Forest & $(100.00)$ & $(100.00)$ & 1.18 \\
\hline Area under non- agricultural uses & 189.51 & 248.83 & $(13.92)$ \\
& $(10.61)$ & 225.29 & 0.40 \\
\hline Barren and unculturable land & 199.57 & $(12.61)$ & -1.40 \\
\hline Permanent pasture and other grazing land & 23.66 & 15.64 & -0.15 \\
\hline Land under misc. tree crops and groves not included in & $(1.32)$ & $(0.87)$ & -0.94 \\
\hline net area sown & 1.62 & 1.50 & \\
\hline Culturable waste land & $(0.09)$ & $(0.08)$ & -0.94 \\
\hline Fallow lands other than current fallows & $(0.96)$ & 17.44 & $(0.70)$ \\
\hline Current fallow & 11.31 & 8.73 & -0.74 \\
\hline Net area sown & $(0.63)$ & $(0.49)$ & -0.17 \\
\hline
\end{tabular}

Figures in brackets indicate percentage value, Source: Statistical abstract of Uttar Pradesh 
Table.3 Land utilization pattern of agro-climatic zone-II

\begin{tabular}{|c|c|c|c|}
\hline & & \multicolumn{2}{|c|}{ (Area 000'ha) } \\
\hline Particulars & TE-2003 & TE-2015 & $\begin{array}{l}\text { CAGR(\%) } \\
2001-15\end{array}$ \\
\hline Geographical area & $\begin{array}{l}2958.53 \\
(100.00)\end{array}$ & $\begin{array}{c}2958.53 \\
(100.00)\end{array}$ & \\
\hline Forest & $\begin{array}{l}268.66 \\
(9.08)\end{array}$ & $\begin{array}{l}244.10 \\
(8.25)\end{array}$ & -0.23 \\
\hline Area under non- agricultural uses & $\begin{array}{r}225.71 \\
(7.63)\end{array}$ & $\begin{array}{l}266.27 \\
(9.00)\end{array}$ & 0.59 \\
\hline Barren and unculturable land & $\begin{array}{l}113.95 \\
(3.85)\end{array}$ & $\begin{array}{l}102.58 \\
(3.47)\end{array}$ & -0.40 \\
\hline Permanent pasture and other grazing land & $\begin{array}{c}5.47 \\
(0.18)\end{array}$ & $\begin{array}{c}5.12 \\
(0.17)\end{array}$ & -0.17 \\
\hline $\begin{array}{l}\text { Land under misc. tree crops and groves not included in net area } \\
\text { sown }\end{array}$ & $\begin{array}{l}15.66 \\
(0.53)\end{array}$ & $\begin{array}{l}29.54 \\
(1.00)\end{array}$ & 1.71 \\
\hline Culturable waste land & $\begin{array}{l}139.12 \\
(4.70)\end{array}$ & $\begin{array}{l}105.30 \\
(3.56)\end{array}$ & -0.86 \\
\hline Fallow lands other than current fallows & $\begin{array}{l}71.78 \\
(2.43\end{array}$ & $\begin{array}{l}51.31 \\
(1.73)\end{array}$ & -1.02 \\
\hline Current fallow & $\begin{array}{l}135.28 \\
(4.57)\end{array}$ & $\begin{array}{l}115.72 \\
(3.91)\end{array}$ & -0.40 \\
\hline Net area sown & $\begin{array}{c}1982.91 \\
(67.02)\end{array}$ & $\begin{array}{c}2041.75 \\
(69.01)\end{array}$ & 0.08 \\
\hline
\end{tabular}

Figures in brackets indicate percentage value, Source: Statistical abstract of Uttar Pradesh

Table.4 Land utilization pattern of agro-climatic zone-III

\begin{tabular}{|l|c|c|c|}
\hline \multicolumn{3}{|c|}{ (Area 000'ha) } \\
\hline Peorticulars & TE-2003 & TE-2015 & $\begin{array}{c}\text { CAGR(\%) } \\
\mathbf{2 0 0 1 - 1 5}\end{array}$ \\
\hline Forest & 3853.03 & 3853.03 \\
& $(100.00)$ & $(100.00)$ & \\
\hline Area under non- agricultural uses & 136.63 & 91.09 & -1.08 \\
& $(3.55)$ & $(2.36)$ & 0.78 \\
\hline Barren and unculturable land & 474.09 & 589.95 & -0.44 \\
\hline Permanent pasture and other grazing land & $(12.30)$ & $(15.31)$ & -0.44 \\
\hline Land under misc. tree crops and groves not included in net area & 80.43 & 70.32 & -0.31 \\
\hline sown & $(2.09)$ & $(1.82)$ & -0.17 \\
\hline Culturable waste land & 14.32 & 11.98 & \\
\hline Fallow lands other than current fallows & $(0.37)$ & $(0.31)$ & -0.37 \\
\hline Current fallow & $(2.04)$ & 71.64 & $(1.86)$ \\
\hline Net area sown & 64.25 & 60.59 & $(1.57)$ \\
\hline
\end{tabular}

Figures in brackets indicate percentage value, Source: Statistical abstract of Uttar Pradesh 
Table.5 Land utilization pattern of agro-climatic zone-IV

\begin{tabular}{|c|c|c|c|}
\hline Particulars & TE-2003 & TE-2015 & $\begin{array}{l}\text { CAGR(\%) } \\
2001-15\end{array}$ \\
\hline Geographical area & $\begin{array}{l}2937.60 \\
(100.00)\end{array}$ & $\begin{array}{l}2937.60 \\
(100.00)\end{array}$ & \\
\hline Forest & $\begin{array}{l}163.41 \\
(5.56)\end{array}$ & $\begin{array}{l}187.38 \\
(6.38)\end{array}$ & 0.50 \\
\hline Area under non- agricultural uses & $\begin{array}{l}355.38 \\
(12.10)\end{array}$ & $\begin{array}{l}396.30 \\
(13.49)\end{array}$ & 0.39 \\
\hline Barren and unculturable land & $\begin{array}{l}35.98 \\
(1.22)\end{array}$ & $\begin{array}{l}27.43 \\
(0.93)\end{array}$ & -0.93 \\
\hline Permanent pasture and other grazing land & $\begin{array}{c}4.53 \\
(0.15)\end{array}$ & $\begin{array}{l}4.19 \\
(0.14)\end{array}$ & -0.26 \\
\hline $\begin{array}{l}\text { Land under misc. tree crops and groves not included in net area } \\
\text { sown }\end{array}$ & $\begin{array}{l}46.35 \\
(1.58)\end{array}$ & $\begin{array}{l}38.36 \\
(1.30)\end{array}$ & -0.77 \\
\hline Culturable waste land & $\begin{array}{l}32.63 \\
(1.11)\end{array}$ & $\begin{array}{l}26.94 \\
(0.91)\end{array}$ & -0.70 \\
\hline Fallow lands other than current fallows & $\begin{array}{l}42.05 \\
(1.43)\end{array}$ & $\begin{array}{l}35.58 \\
(1.20)\end{array}$ & -0.60 \\
\hline Current fallow & $\begin{array}{l}104.47 \\
(3.56)\end{array}$ & $\begin{array}{l}94.48 \\
(3.20)\end{array}$ & -0.14 \\
\hline Net area sown & $\begin{array}{c}2152.82 \\
(73.28)\end{array}$ & $\begin{array}{c}2144.90 \\
(72.57)\end{array}$ & -0.02 \\
\hline
\end{tabular}

Figures in brackets indicate percentage value, Source: Statistical abstract of Uttar Pradesh

Table.6 Land utilization pattern of agro-climatic zone-V

\begin{tabular}{|l|c|c|c|}
\hline Particulars & TE-2003 & TE-2015 & $\begin{array}{c}\text { CAGR(\%) } \\
\mathbf{2 0 0 1 - 1 5}\end{array}$ \\
\hline Geographical area & 2230.94 & 2230.94 \\
& $(100.00)$ & $(100.00)$ & \\
\hline Forest & 65.54 & 55.17 & -0.44 \\
& $(2.94)$ & $(2.47)$ & \\
\hline Area under non- agricultural uses & 201.10 & 251.65 & 0.79 \\
& $(9.01)$ & $(11.26)$ & \\
\hline Barren and unculturable land & 58.45 & 43.05 & -1.17 \\
& $(2.62)$ & $(1.93)$ & \\
\hline Permanent pasture and other grazing land & 7.77 & 7.55 & -0.08 \\
\hline Land under misc. tree crops and groves not included in & $(0.35)$ & $(0.34)$ & \\
\hline net area sown & 8.36 & 13.91 & 1.12 \\
\hline Culturable waste land & $(0.37)$ & $(0.62)$ & -0.73 \\
\hline Fallow lands other than current fallows & 59.11 & 47.19 & \\
\hline Current fallow & $(2.65)$ & $(2.11)$ & -1.29 \\
\hline Net area sown & 73.04 & 50.43 & -0.11 \\
\hline
\end{tabular}

Figures in brackets indicate percentage value, Source: Statistical abstract of Uttar Pradesh 
Table.7 Land utilization pattern of agro-climatic zone-VI

\begin{tabular}{|c|c|c|c|}
\hline Particulars & TE-2003 & TE-2015 & $\begin{array}{l}\text { CAGR(\%) } \\
2001-15\end{array}$ \\
\hline Geographical area & $\begin{array}{r}1688.07 \\
(100.00)\end{array}$ & $\begin{array}{l}1688.07 \\
(100.00)\end{array}$ & - \\
\hline Forest & $\begin{array}{l}68.30 \\
(4.05)\end{array}$ & $\begin{array}{l}76.55 \\
(4.53)\end{array}$ & 0.33 \\
\hline Area under non- agricultural uses & $\begin{array}{l}205.60 \\
(12.18)\end{array}$ & $\begin{array}{l}247.95 \\
(14.69)\end{array}$ & 0.66 \\
\hline Barren and unculturable land & $\begin{array}{l}30.06 \\
(1.78)\end{array}$ & $\begin{array}{l}17.94 \\
(1.06)\end{array}$ & -1.92 \\
\hline Permanent pasture and other grazing land & $\begin{array}{c}2.49 \\
(0.15)\end{array}$ & $\begin{array}{c}2.58 \\
(0.16)\end{array}$ & 0.21 \\
\hline $\begin{array}{l}\text { Land under misc. tree crops and groves not included in net } \\
\text { area sown }\end{array}$ & $\begin{array}{l}11.91 \\
(0.71)\end{array}$ & $\begin{array}{c}4.38 \\
(0.27)\end{array}$ & -3.07 \\
\hline Culturable waste land & $\begin{array}{l}22.54 \\
(1.34)\end{array}$ & $\begin{array}{l}15.12 \\
(0.92)\end{array}$ & -1.40 \\
\hline Fallow lands other than current fallows & $\begin{array}{l}24.83 \\
(1.47)\end{array}$ & $\begin{array}{l}18.19 \\
(1.08)\end{array}$ & -0.90 \\
\hline Current fallow & $\begin{array}{l}32.55 \\
(1.93)\end{array}$ & $\begin{array}{l}52.94 \\
(3.14)\end{array}$ & 1.64 \\
\hline Net area sown & $\begin{array}{l}1289.78 \\
(76.41)\end{array}$ & $\begin{array}{l}1214.58 \\
(71.95)\end{array}$ & -0.23 \\
\hline
\end{tabular}

Figures in brackets indicate percentage value, Source: Statistical abstract of Uttar Pradesh

Table.8 Land utilization pattern of agro-climatic zone-VII

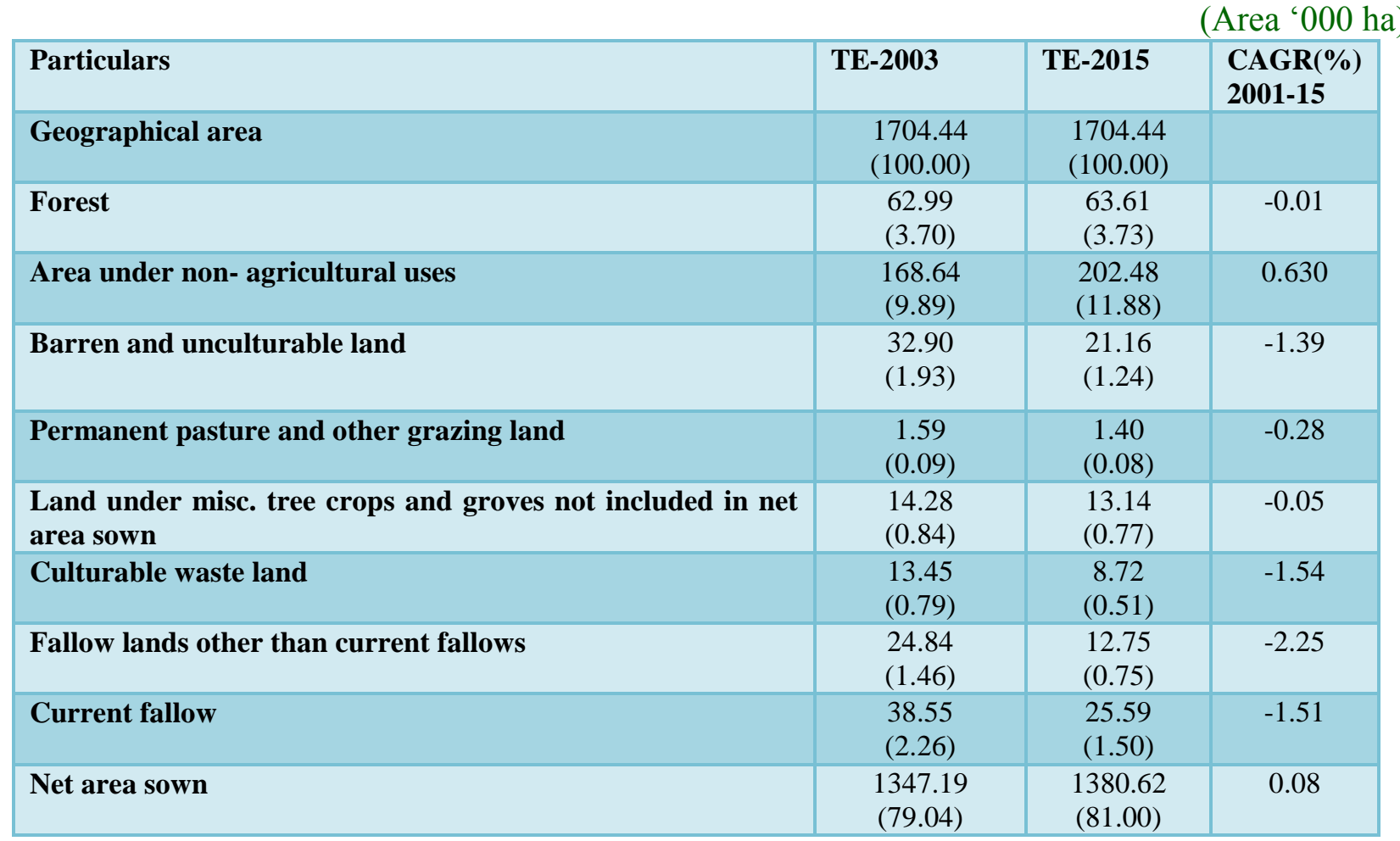

Figures in brackets indicate percentage value, Source: Statistical abstract of Uttar Pradesh 
Table.9 Land utilization pattern of agro-climatic zone-VIII

\begin{tabular}{|c|c|c|c|}
\hline Particulars & TE-2003 & TE-2015 & $\begin{array}{l}\text { CAGR(\%) } \\
2001-15\end{array}$ \\
\hline Geographical area & $\begin{array}{l}1377.61 \\
(100.00)\end{array}$ & $\begin{array}{l}1377.61 \\
(100.00)\end{array}$ & \\
\hline Forest & $\begin{array}{l}477.77 \\
(34.68)\end{array}$ & $\begin{array}{l}444.03 \\
(32.23)\end{array}$ & -0.30 \\
\hline Area under non- agricultural uses & $\begin{array}{l}121.39 \\
(8.81)\end{array}$ & $\begin{array}{l}157.11 \\
(11.40)\end{array}$ & 0.87 \\
\hline Barren and unculturable land & $\begin{array}{l}32.54 \\
(2.36)\end{array}$ & $\begin{array}{l}26.92 \\
(1.95)\end{array}$ & -0.65 \\
\hline Permanent pasture and other grazing land & $\begin{array}{c}1.81 \\
(0.13)\end{array}$ & $\begin{array}{c}1.54 \\
(0.11)\end{array}$ & -0.52 \\
\hline $\begin{array}{l}\text { Land under misc. tree crops and groves not included in net } \\
\text { area sown }\end{array}$ & $\begin{array}{l}58.80 \\
(4.27)\end{array}$ & $\begin{array}{l}77.32 \\
(5.61)\end{array}$ & 1.24 \\
\hline Culturable waste land & $\begin{array}{l}33.65 \\
(2.44)\end{array}$ & $\begin{array}{l}30.79 \\
(2.23)\end{array}$ & -0.26 \\
\hline Fallow lands other than current fallows & $\begin{array}{l}36.84 \\
(2.67)\end{array}$ & $\begin{array}{l}44.01 \\
(3.19)\end{array}$ & 0.81 \\
\hline Current fallow & $\begin{array}{l}49.75 \\
(3.61)\end{array}$ & $\begin{array}{l}110.53 \\
(8.02)\end{array}$ & 2.63 \\
\hline Net area sown & $\begin{array}{l}565.05 \\
(41.02)\end{array}$ & $\begin{array}{l}489.61 \\
(35.54)\end{array}$ & -0.47 \\
\hline
\end{tabular}

Figures in brackets indicate percentage value, Source: Statistical abstract of Uttar Pradesh

Table.10 Land utilization pattern of agro-climatic zone-IX

\begin{tabular}{|c|c|c|c|}
\hline Particulars & TE-2003 & TE-2015 & $\begin{array}{l}\text { CAGR(\%) } \\
2001-15\end{array}$ \\
\hline Geographical area & $\begin{array}{l}5664.82 \\
(100.00)\end{array}$ & $\begin{array}{l}5664.82 \\
(100.00)\end{array}$ & \\
\hline Forest & $\begin{array}{c}255.92 \\
(4.52)\end{array}$ & $\begin{array}{r}247.51 \\
(4.37)\end{array}$ & -0.08 \\
\hline Area under non-agricultural uses & $\begin{array}{l}549.65 \\
(9.70)\end{array}$ & $\begin{array}{l}671.51 \\
(11.85)\end{array}$ & 0.61 \\
\hline Barrenand unculturable land & $\begin{array}{l}187.99 \\
(3.32)\end{array}$ & $\begin{array}{l}143.25 \\
(2.53)\end{array}$ & -0.97 \\
\hline Permanent pasture and other grazing land & $\begin{array}{l}30.20 \\
(0.53)\end{array}$ & $\begin{array}{l}29.53 \\
(0.52)\end{array}$ & -0.07 \\
\hline $\begin{array}{l}\text { Land under miscellaneous tree crops and groves not included } \\
\text { in net area sown }\end{array}$ & $\begin{array}{l}94.30 \\
(1.66)\end{array}$ & $\begin{array}{l}66.04 \\
(1.17)\end{array}$ & -1.30 \\
\hline Culturable waste land & $\begin{array}{l}141.31 \\
(2.49)\end{array}$ & $\begin{array}{l}109.50 \\
(1.93)\end{array}$ & -0.90 \\
\hline Fallow lands other than current fallows & $\begin{array}{c}216.91 \\
(3.83)\end{array}$ & $\begin{array}{l}189.37 \\
(3.34)\end{array}$ & -0.55 \\
\hline Current fallow & $\begin{array}{l}371.02 \\
(6.55)\end{array}$ & $\begin{array}{l}360.31 \\
(6.36)\end{array}$ & -0.04 \\
\hline Net area sown & $\begin{array}{l}3817.52 \\
(67.39)\end{array}$ & $\begin{array}{l}3731.61 \\
(65.87)\end{array}$ & -0.05 \\
\hline
\end{tabular}

Figures in brackets indicate percentage value, Source: Statistical abstract of Uttar Pradesh 
There was drastic decline in net sown area due to a larger increase in area under nonagricultural land, current fallow land, forest land and permanent pastures and other grazing land. Forest land had increased from $4.05 \%$ in TE-2003 to $4.64 \%$ in TE-2015, its compound growth rate was estimated to be $0.33 \%$. The area put to non-agricultural uses has gone up from $12.18 \%$ to $15.03 \%$ showing a positive growth rate of $0.67 \%$ per annum. Current fallow land too indicated rising trend. Other reason for declining in net sown area may probably be that the Western plain zone constituted densely populated district like Ghaziabad, Meerut, Bhaghpat, Bulandsahar etc. which emphasized for construction of more of dwelling houses, roads etc.

\section{Agro-climatic zone-VII}

Changes in land use pattern of agro-climatic zone-VII (Mid western plain zone) as presented in Table 8 indicated the increase in net sown area from $79.04 \%$ in TE-2003 to $79.83 \%$ in TE-2015. In the zone all categories of land except area under non-agricultural uses were assessed declining. The reason for increase in non-agricultural land has already been explained earlier.

\section{Agro-climatic zone-VIII}

Changes in land use pattern in agro-climatic zone-VIII (Vindhya zone) as given in Table 9 observed that net area sown had declined from $41.02 \%$ in TE-2003 to $35.43 \%$ in TE2015 with negative CGR (-0.47\% per annum).

The probable reason behind declining in net sown area may be due to rise in nonagricultural land, land under misc. tree crops and groves, fallow lands other than current fallows and current fallows.

\section{Agro-climatic zone-IX}

Land use pattern in agro-climatic zone-IX
(Central zone) given in Table 10 depicted the decline in the net sown area from $67.39 \%$ in TE-2003 to $67.13 \%$ in TE-2015. It was also confirmed from it negative growth rate (-.05\% per annum). Decline in net sown was probably due to increase in area under nonagricultural uses, at the rate of $9.70 \%$ in TE2003 to $11.85 \%$ in TE-2015 with $0.61 \%$.per annum growth rate.

All other categories of land were observed declining. The central zone consists of those districts which are densely populated like Kanpur, Lucknow, Allahabad etc. Kanpur is one of the most industrialized districts of UP. Due to large opportunities of employment and for better education, large number of population migrated to this area. The unprecedented population growth leads to unplanned and unmanaged developmental activities. These unmanaged developmental activities causes pressures on land resulted in construction of several infrastructures like roadways, buldings, etc. Thus, agricultural land has been converted in to non-agricultural land.

The above study revealed that net sown area declined in the state as a whole and also in almost agro-climatic zones viz. zone-I, zoneIII, zone-IV, zone-VI, zone-VIII and zone-IX except three agro-climatic zones viz. zone-II, zone-V and zone-VII in which net area sown showed rising trend. Net area sown had declined in both the state and in agro-climatic zones because of increase in non-agricultural land, current fallow land and fallow land other than current fallow land. Unprecedented population growth resulted in construction of infrastructures like building, roadways, etc. Thus, agricultural-land was converted into non-agricultural land for industrialization and urbanization purposes. Overall, it can be concluded that there is continuous expansion of land towards non-agricultural lands. Declining net sown area is major challenge for policy makers as it will ultimately have 
adverse effect on food security of the ever growing population of the state. Hence, it is need of the day to increase productivity of the crops as the land is limited and it can't be expanded. There is less scope for horizontal agriculture thus it is time to emphasized on vertical agriculture.

\section{References}

Ahlawat Joginder (2017). A geographical review of the land use patterns of Kanpur city, India, Internationlal Journal of Humanities Social Sciences and Invention, 6(7): 21-27.

Bakker, M.M., \& van Doorn, A.M. (2009).Farmer-specific relationships between land use change and landscape factors: introducing agents in empirical land use modelling. Land Use Policy, 26: 809-817.

Bamwerinde, W., Bashaasha, B., Ssembajjwe, W. \& Place, F. (2006). The puzzle of idle land in the densely populated kigezi highlands of south-western Uganda. International Journal for Environment and Development, 3(1): 1-13.

FAO (1998). Aquaculture Production on Statistics, 1987-1996. FAO, Rome. FAO Fisheries Circular No.815, Rev$10,197$.

FAO/UNEP (1999). Terminology for integrated resources planning and management. FAO, Rome.

Gellrich, M., Baur, P., Koch, B., \&
Zimmermann, N.K. (2007). Agricultural land abandonment and natural forest regrowth in the Swiss mountains: A Spatially Explicit Economic Analysis. Agriculture. Ecosystems and Environment, 118: 93-108.

Kandrika, S. and Roy, P.S. (2008). Land use and land cover classification of Orissa multi-temporal IRS-P6 awifs data: A decision tree approach. International Journal of Applied Earth Observation and Geoinformation, 10, 186-193.

Kumar, J. (1986). Land use analysis: A case study of Nalandadistrict, Bihar, InterIndia Publication, New Delhi, 64.

Pandey, B.V. and Singh, S. (2019). "Agricultural land-use pattern in Raebareli district, Uttar Pradesh: A geographical appraisal", International Journal of Research and Analytical Reviews, 6(1).

Rathee Geetika (2014).Trends of land-use change in India. http:// www.researchgate.net/ publication/291242250.

Singh, S.K. ; Mishra, S. and Rai, A.K. (2015). A Geographical view of land use pattern in Mirzapur district. https://www.researchgate.net/publicatio $n / 282076168$.

Young, A. (1998). Land Resources; Now and for the future. Cambridge University Press, 319.

\section{How to cite this article:}

Srishti Kushwaha, D.K. Sinha, Ashok Yadav and Nasim Ahmad. 2020. Changes in Land Use Pattern in Uttar Pradesh: A Zone-wise Analysis. Int.J.Curr.Microbiol.App.Sci. 9(01): 16891699. doi: https://doi.org/10.20546/ijcmas.2020.901.186 